LINES OF THOUGHT 



\section{LINES OF THOUGHT}

Claudia Brodsky Lacour

Discourse,

Architectonics,

and the

Origin of

Modern

Philosophy

Duke University Press Durham and London 1996 
C 1996 Duke University Press

All rights reserved

Printed in the United States of America on acid-free paper $@$

Typeset in Adobe Garamond by Tseng Information Systems, Inc.

Library of Congress Cataloging-in-Publication Data

appear on the last printed page of this book. 
For Camille 
